\title{
Temperature Threshold and Preservation of Signaling for Mitochondrial Membrane Proteins during Ischemia in Rabbit Heart ${ }^{1}$
}

\author{
Xue-Han Ning, Cheng-Su Xu, Ying C. Song, Yun Xiao, Ying-Jia Hu, \\ Flavian M. Lupinetti, and Michael A. Portman
}

Division of Cardiology, Department of Pediatrics, and Division of Cardiovascular Surgery, Department of Surgery, University of Washington, Seattle, Washington 98195 U.S.A.; and Children's Hospital and Regional Medical Center, Seattle, Washington 98105, U.S.A.

\begin{abstract}
Temperature modulates both myocardial energy requirements and production. We have previously demonstrated that myocardial protection induced by hypothermic adaptation preserves expression of genes regulating heat shock protein and the nuclear-encoded mitochondrial proteins, the adenine nucleotide translocator isoform $1\left(\mathrm{ANT}_{1}\right)$, and the $\beta$ subunit of $\mathrm{F}_{1}$-ATPase $\left(\beta \mathrm{F}_{1}\right.$-ATPase). This preservation is associated with a reduction in ATP depletion similar to that noted in cardioplegic arrested hearts preserved at a critical temperature $\left(30^{\circ} \mathrm{C}\right)$ or below. We tested the hypothesis that expression of these genes may also be subject to this temperature threshold phenomenon. Isolated perfused rabbit hearts were subjected to ischemic cardioplegic arrest at 4,30 , or $34^{\circ} \mathrm{C}$ for $120 \mathrm{~min}$. Cardiac function indices and steady-state mRNA levels for $\mathrm{ANT}_{1}, \beta \mathrm{F}_{1}-\mathrm{ATPase}$, and HSP70-1 were measured prior to ischemia (B) and after $45 \mathrm{~min}$ of reperfusion. Cardiac function was significantly depressed in the $34^{\circ} \mathrm{C}$ group. Ischemia at $34^{\circ} \mathrm{C}$ reduced steady-state mRNA levels for $\mathrm{ANT}_{1}$ and $\beta \mathrm{F}_{1}-\mathrm{ATPase}$ from $\mathrm{B}$, but these levels were similarly preserved at 4 and $30^{\circ} \mathrm{C}$. HSP70-1 levels were mildly elevated (fourfold) above B to similar levels at all three temperatures. These results indicate that mRNA expression for $\mathrm{ANT}_{1}$ and $\beta \mathrm{F}_{1}-\mathrm{ATPase}$ is specifically preserved in a pattern consistent with the temperature threshold phenomenon. HSP70-1 expression is not influenced by ischemic temperature. Preservation of gene expression for these mitochondrial proteins implies that signaling for mitochondrial biogenesis or resynthesis is maintained after ischemic insult. () 1998 Academic Press
\end{abstract}

Key Words: adaptation; $\mathrm{ANT}_{1} ; \beta \mathrm{F}_{1}$-ATPase; cardioplegia; HSP70-1; hypothermia; myocardial ischemia; myocardial reperfusion; threshold.

Temperature protects ischemic myocardium $(2,3,6,7,15,34,36,38)$ and modulates both myocardial energy requirements and production (27). The relationship between energy supply and demand in the cardioplegic arrested heart remains fairly constant in the temperature range between 4 and $30^{\circ} \mathrm{C}(27)$, which is frequently used during cardiac surgical procedures. The myocardial supply/demand ratio demonstrates a threshold phenomenon by deteriorating rapidly at temperatures above $30^{\circ} \mathrm{C}$ (27). Accelerated ATP depletion and inability to reestablish highenergy phosphate stores during reperfusion accompany this deterioration. Thus, $30^{\circ} \mathrm{C}$ represents a critical temperature point (39), which

Received December 22, 1997; accepted April 3, 1998.

${ }^{1}$ This study was presented in part at the XXXIII International Congress of Physiological Sciences, July, 1997, St. Petersburg, Russia. triggers acceleration of metabolic energy utilization rate above the energy production rate. Provision of glucose as substrate in the cardioplegia solution can partially ameliorate this metabolic imbalance by promoting anaerobic ATP production (27).

Recently, we have demonstrated that hypothermic exposure at $30^{\circ} \mathrm{C}$ prior to warm ischemia preserves myocardial function and ATP stores after reperfusion (28). This response represents an adaptation, whereby the heart becomes tolerant to a second exposure of the same or alternative type of stress. Hypothermic exposure induces a metabolic down-regulation, which persists during subsequent warm ischemia and may represent the principal factor in this down-regulation. This response differs from simple cold exposure during ischemia. Consistent with other forms of coldinduced adaptation $(18,20,21)$, alterations in expression of specific genes occur. These include 
preservation of steady-state mRNA levels for genes regulating heat shock proteins and the nuclear-encoded mitochondrial membrane proteins, the adenine nucleotide translocator (ANT), and the $\beta$ subunit of $F_{1}$-ATPase $\left(\beta F_{1}\right.$-ATPase). This preservation is associated with a reduction in ATP depletion (28) that is similar to that noted in cardioplegic arrested hearts preserved at $30^{\circ} \mathrm{C}$ or below. Accordingly, we posed the hypothesis that expression of these genes may be subject to this temperature threshold phenomenon. Ischemic temperatures above $30^{\circ} \mathrm{C}$ may affect expression of these genes. To test this hypothesis steady-state mRNA levels were measured after reperfusion in rabbit hearts subjected to different ischemic temperatures during cardioplegic arrest. These data show that gene expression for the mitochondrial membrane proteins is consistent with the temperature threshold hypothesis. However, HSP70-1 gene expression does not vary according to ischemic temperature.

\section{MATERIALS AND METHODS}

\section{Preparation of Isolated Heart}

White New Zealand rabbits (male or female, 2.3-2.7 kg body wt) were heparinized (700 $\mathrm{U} / \mathrm{kg}$, intravenously) and anesthetized with sodium pentobarbital (45 mg/kg, intravenously). Under median sternotomy, the heart was rapidly excised and immersed momentarily in ice-cold physiological salt solution (PSS), $\mathrm{pH} 7.4$, containing $118.0 \mathrm{mmol} / \mathrm{L} \mathrm{NaCl}, 4.0 \mathrm{mmol} / \mathrm{L} \mathrm{KCl}$, $22.3 \mathrm{mmol} / \mathrm{L} \mathrm{NaHCO}_{3}, 11.1 \mathrm{mmol} / \mathrm{L}$ glucose, $0.66 \mathrm{mmol} / \mathrm{L} \mathrm{KH} \mathrm{KHO}_{4}, 1.23 \mathrm{mmol} / \mathrm{L} \mathrm{MgCl}_{2}$, and $2.38 \mathrm{mmol} / \mathrm{L} \mathrm{CaCl}_{2}(27,28)$. The aorta was cannulated in the Langendorff mode and the heart was perfused with PSS equilibrated with $95 \% 0_{2}-5 \% \mathrm{CO}_{2}$ at $37^{\circ} \mathrm{C}$. Perfusion pressure was maintained at $90 \mathrm{~mm} \mathrm{Hg}$ and PSS passed twice through 3.0- $\mu \mathrm{m}$-pore size filters. An incision was made in the left atrium, and a fluidfilled latex balloon was passed through the mitral orifice and placed in the left ventricle. The balloon was connected to a pressure transducer for continuous measurement of left ventricular pressure (LVP) and the first derivative of LVP $(d P / d t)$. The caudal vena cavum, the left and right cranial vena cava, and the azygous vein were ligated. The pulmonary artery was cannulated for collection of coronary effluent. The coronary flow was measured with a flow meter (T201, Transonic Systems Inc., Ithaca, NY, U.S.A.).

The analog signals of left ventricular mechanical function were continuously recorded on a pressurized ink chart recorder (Gould, Inc., Cleveland, OH, U.S.A.), and an on-line computer (Macintosh, Biopac Analog Signal Acquisition System). To characterize cardiac function, developed pressure (DP) is defined as peak systolic pressure minus end-diastolic pressure. To provide an estimate of myocardial work, the product of DP and heart rate (HR) was calculated (PRP, mm $\mathrm{Hg} / \mathrm{min}$ ). Myocardial oxygen consumption $\left(\mathrm{MV}_{\mathrm{O}_{2}}\right)$ was calculated as the expression $\mathrm{MV}_{\mathrm{O}_{2}}=\mathrm{CF} \times\left[\left(\mathrm{Pa}_{\mathrm{O}_{2}}-\mathrm{Pv}_{\mathrm{O}_{2}}\right) \times\right.$ (c/760)], where CF is coronary flow $(\mathrm{ml} / \mathrm{min})$, $\left(\mathrm{Pa}_{\mathrm{O}_{2}}-\mathrm{Pv}_{\mathrm{O}_{2}}\right)$ is the difference in the partial pressure of oxygen $\left(\mathrm{P}_{\mathrm{O}_{2}}, \mathrm{~mm} \mathrm{Hg}\right)$ between perfusate and coronary effluent flow, and $\mathrm{c}$ is the Bunsen solubility coefficient of $\mathrm{O}_{2}$ in perfusate at $37^{\circ} \mathrm{C}\left(22.7 \mu \mathrm{l} \mathrm{O}_{2} \times \mathrm{atm}^{-1} \times \mathrm{ml}^{-1}\right.$ perfusate $)$ (27). Oxygen extraction was calculated as the expression $\mathrm{O}_{2} \mathrm{EXT}=\mathrm{MV}_{\mathrm{O}_{2}}$ /oxygen content in the perfusate. Procedures followed were in accordance with institutional and NIH guidelines on treatment of animals.

RNA isolation. After removal of excess fat and connective tissues, the left ventricular wall was briefly blotted on nine-layer gauze, then frozen in liquid nitrogen, and stored at $-80^{\circ} \mathrm{C}$. An aliquot $(100 \mathrm{mg})$ of the frozen tissue was pulverized and homogenized and total RNA was extracted with a RNA Isolation kit (Ambion Inc., Austin, TX, U.S.A.). RNA samples were tested by ultraviolet absorption at A260 $\mathrm{nM}$ to determine the concentration. The quality and concentration of the RNA samples were further confirmed by electrophoresis on denatured $1 \%$ agarose gels (28).

Northern blot analysis. For Northern blot analysis, $15 \mu \mathrm{g}$ of RNA was denatured and electrophoresed in a $1 \%$ formaldehyde agarose gel, then transferred to a nitrocellulose transfer membrane (Micron Separations Inc., Westboro, MA, U.S.A.), and cross-linked to the membrane 
with short-wave ultraviolet cross linker. The prehybridizing and hybridizing solutions contained $50 \%$ formamide, $1 \times$ Denhardt's solution, $6 \times$ SSPE, and $1 \%$ sodium dodecyl sulfate (SDS). Complementary DNA (cDNA) probes were labeled with $\left[{ }^{32} \mathrm{P}\right] \mathrm{dCTP}$ by random primer extension (PRIME-IT II, Stratagene, La Jolla, CA, U.S.A.) and added to the hybridizing solution to a specific activity. Hybridization was carried out at $42^{\circ} \mathrm{C}$ for $18 \mathrm{~h}$. The blots were then washed several times with a final wash in $2 \times$ standard sodium citrate and $0.1 \%$ SDS at $65^{\circ} \mathrm{C}$. The relative amount of mRNAs was evaluated using a PhosphorImager (Model 400S, Molecular Dynamics, Sunnyvale, CA, U.S.A.). The same size area at each band was taken to measure the intensity and the same size area at the closest upstream position of each band was taken as the background of the image, respectively. The blots were also exposed on Kodak X-Omat film (Eastman Kodak Co., Rochester, NY, U.S.A.) at $-70^{\circ} \mathrm{C}$. RNA loading was normalized by comparison to that of 28 s ribosomal RNA (28). Adenine nucleotide translocase isoform $1\left(\mathrm{ANT}_{1}\right)$ mRNA levels were detected using a 1.4-kb $\mathrm{ANT}_{1}$ cDNA fragment cloned from a human skeletal muscle library (ATCC, Rockville, Maryland) (23, 35). $\beta \mathrm{F}_{1}$-ATPase mRNA levels were detected using a $1.8-\mathrm{kb} \beta \mathrm{F}_{1}$ ATPase cDNA fragment cloned from a human HeLa cell line library (ATCC) $(4,37)$. An inducible heat shock protein (HSP70-1) mRNA level was detected by a 1.7-kb cDNA fragment cloned from human hippocampus (ATCC) (17, 21). To compare different mRNA levels in the same myocardial sample, aliquots of $15-\mu \mathrm{g}$ total RNA from the myocardium were analyzed by means of sequentially reprobing the membranes with $28 \mathrm{~s}, \mathrm{ANT}_{1}, \quad \beta \mathrm{F}_{1}$-ATPase, and HSP70-1 cDNA probes.

\section{Experimental Protocols}

After instrumentation and performing calibrations were completed, left ventricular balloon volumes were varied over a range of values to construct left ventricular function curves. In this manner, it is possible to define a specific balloon volume that is associated with a developed pressure between 100 and $140 \mathrm{~mm} \mathrm{Hg}$. This volume was maintained at the same level during baseline and reperfusion conditions. The intraventricular balloon volumes were not adjusted to produce specific end-diastolic pressures (rather, we defined a level of systolic pressure development), but end-diastolic pressures at baseline greater than $10 \mathrm{~mm} \mathrm{Hg}$ were not considered acceptable (26). Data from hearts characterized by developed pressures less than $100 \mathrm{~mm} \mathrm{Hg}$ or greater than $140 \mathrm{~mm} \mathrm{Hg}$ were not used. Baseline data were obtained after an equilibration period of approximately $30 \mathrm{~min}$. The same procedures were followed in each experiment. During the baseline period, data were obtained with the hearts maintained at $37^{\circ} \mathrm{C}$ by water circulated through the organ bath. The pulmonary outflow temperature was monitored continuously with a thermal probe to adjust the temperature of the infusion. During ischemia, the PSS infusion was stopped and $60 \mathrm{~mL}$ of oxygenated St. Thomas' cardioplegic solution $(\mathrm{CP})$ at $4{ }^{\circ} \mathrm{C}$ was injected into the aorta at a rate of $1 \mathrm{~mL} / \mathrm{s}$ to begin the $2-\mathrm{h}$ ischemia. The organ bath temperature was changed to 4,30 , or $34^{\circ} \mathrm{C}$ during ischemia. Fifteen milliliters of St. Thomas cardioplegic solution $\left(4^{\circ} \mathrm{C}\right)$ was injected every $30 \mathrm{~min}$ thereafter. The St. Thomas cardioplegic solution contained $109.0 \mathrm{mmol} / \mathrm{L} \mathrm{NaCl}, 25.0$ $\mathrm{mmol} / \mathrm{L} \mathrm{KCl}, 21.9 \mathrm{mmol} / \mathrm{L} \mathrm{NaHCO}_{3}, 16.0$ $\mathrm{mmol} / \mathrm{L} \mathrm{MgCl}_{2}$, and $0.8 \mathrm{mmol} / \mathrm{L} \mathrm{CaCl}_{2}$. Repeated administration of cardioplegic solution is used commonly in the clinical arena and is consistent with experimental studies that have reported previously $(9,19,25,28)$. When the 2 -h ischemic period was ended, the hearts were reperfused with oxygenated PSS at $37^{\circ} \mathrm{C}$ and the water bath temperature was increased to $37^{\circ} \mathrm{C}$. During the $45 \mathrm{~min}$ of reperfusion, hemodynamic data were recorded to compare with baseline data and to determine the degree of functional recovery in each heart. After reperfusion, hearts were quickly placed in liquid nitrogen for RNA measurements. Figure 1 briefly illustrates the protocol.

In previous studies, the functional recovery 


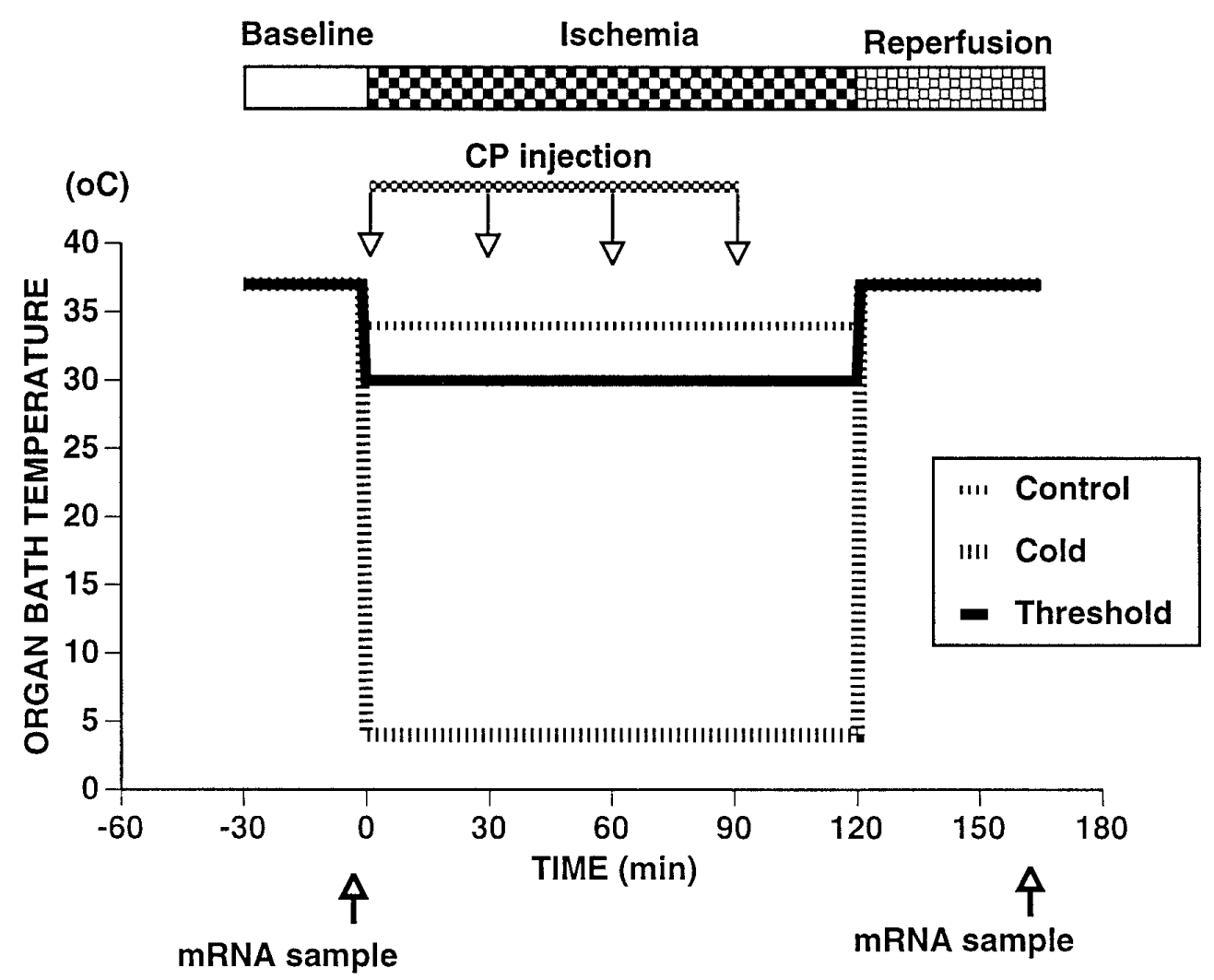

FIG. 1. Experimental protocol. The abbreviations used are: $\mathrm{CP}$, cardioplegic solution; Control, control hearts treated at $34^{\circ} \mathrm{C}$ ischemia; Cold, hearts treated at $4^{\circ} \mathrm{C}$ ischemia; Threshold, hearts treated at $30^{\circ} \mathrm{C}$ threshold temperature. Function signals were continuously recorded during the experiments.

was similar at 4,18 , and $30^{\circ} \mathrm{C}$ ischemia, but the recovery was dramatically decreased at $34^{\circ} \mathrm{C}$ ischemia (27). To simplify the protocol, in this study 20 hearts were divided into $4^{\circ} \mathrm{C}(n=4)$, $30^{\circ} \mathrm{C}(n=4)$, and $34^{\circ} \mathrm{C}(n=8)$ ischemic groups as well as a baseline control group $(n=$ $4)$. In order to evaluate the alteration of mRNA levels of genes, values of ischemic groups were compared to the baseline control value.

\section{Statistical Analysis}

Values reported are means \pm standard error (SE) in the text, tables, and figures. The Statview 4.5 (FPV) program (Abacus Concepts, Inc., Berkeley, CA, U.S.A.) was used for statistical analysis. Data were evaluated with repeated measures analysis of variance within groups and single-factor analysis of variance across groups. When significant $F$ values were obtained, Scheffe's test was used to distinguish which groups differed from each other significantly. The criterion for significance was taken to be $P<0.05$ for all comparisons.

\section{RESULTS}

\section{Functional Parameters}

Baseline. The heart weights were similar in the groups $(6.6 \pm 0.5,6.9 \pm 0.4$, and $7.5 \pm$ $0.8 \mathrm{~g}$ in the 4,30 , and $34^{\circ} \mathrm{C}$ groups, respectively; $P>0.05$ ). The end diastolic left ventricular pressure was adjusted to similar levels $(2.5 \pm 0.5,3.4 \pm 0.3$, and $1.7 \pm 0.3 \mathrm{~mm} \mathrm{Hg}$ in the 4,30 , and $34^{\circ} \mathrm{C}$ groups with the ventricular volume at $1.2 \pm 0.1,1.3 \pm 0.1$, and $1.7 \pm 0.1$ $\mathrm{ml}$, respectively) at baseline conditions. There 
TABLE 1

Hemodynamics (Means \pm SE)

\begin{tabular}{|c|c|c|c|}
\hline Group & $4^{\circ} \mathrm{C}(n=4)$ & $30^{\circ} \mathrm{C}(n=4)$ & $34^{\circ} \mathrm{C}(n=8)$ \\
\hline \multicolumn{4}{|l|}{$\mathrm{DP}(\mathrm{mm} \mathrm{Hg})$} \\
\hline Baseline & $116.2 \pm 5.0$ & $114.2 \pm 4.9$ & $119.0 \pm 4.5$ \\
\hline REP & $69.5 \pm 4.1$ & $66.1 \pm 3.0$ & $38.0 \pm 6.4^{*}$ \\
\hline \multicolumn{4}{|c|}{$d P / d t_{\max }(\mathrm{mm} \mathrm{Hg} / \mathrm{s})$} \\
\hline Baseline & $2037 \pm 168$ & $2024 \pm 235$ & $1875 \pm 211$ \\
\hline REP & $1095 \pm 59$ & $1049 \pm 103$ & $529 \pm 101 *$ \\
\hline \multicolumn{4}{|c|}{$-d P / d t_{\max }(\mathrm{mm} \mathrm{Hg} / \mathrm{s})$} \\
\hline Baseline & $1420 \pm 65$ & $1423 \pm 111$ & $1260 \pm 159$ \\
\hline REP & $977 \pm 57$ & $887 \pm 37$ & $449 \pm 85^{*}$ \\
\hline \multicolumn{4}{|l|}{ HR (Beats/min) } \\
\hline Baseline & $200.8 \pm 20.4$ & $212.0 \pm 17.5$ & $187.9 \pm 11.8$ \\
\hline REP & $226.8 \pm 16.1$ & $214.8 \pm 17.3$ & $173.0 \pm 18.3$ \\
\hline \multicolumn{4}{|c|}{$\operatorname{PRP}\left(10^{3} \mathrm{~mm} \mathrm{Hg} / \mathrm{min}\right)$} \\
\hline Baseline & $23.29 \pm 2.37$ & $24.14 \pm 1.84$ & $20.81 \pm 2.71$ \\
\hline REP & $15.75 \pm 1.42$ & $14.19 \pm 1.20$ & $6.04 \pm 0.95^{*}$ \\
\hline \multicolumn{4}{|c|}{$\mathrm{MV}_{\mathrm{O}_{2}}(\mu \mathrm{l} / \mathrm{g} / \mathrm{min})$} \\
\hline Baseline & $122.3 \pm 13.9$ & $111.0 \pm 5.4$ & $94.0 \pm 5.1$ \\
\hline REP & $87.3 \pm 12.3$ & $80.2 \pm 3.0$ & $34.0 \pm 5.3^{*}$ \\
\hline
\end{tabular}

Note. The hemodynamic indices were determined in isolated reperfused hearts at baseline and after 45 min of reperfusion (REP) as described under Materials and Methods at 4, 30, and $34^{\circ} \mathrm{C}$ ischemic groups, respectively. The abbreviations used are: DP, left ventricular developed pressure; $d P / d t_{\max }$, positive maximum of the first derivative of left ventricular pressure; $-d P / d t_{\text {max }}$, negative maximum of the first derivative of left ventricular pressure; HR, heart rate; PRP, product of HR and DP; $\mathrm{MV}_{\mathrm{O}_{2}}$, myocardial oxygen consumption. ${ }^{*} P<0.05$ vs $4^{\circ} \mathrm{C}$ group.

were no significant differences between groups in DP, $\pm d P / d t_{\text {max }}$, HR, PRP, or $\mathrm{MV}_{\mathrm{O}_{2}}$ (Table 1).

Functional recovery during reperfusion. In Table 1 and Fig. 2, the data demonstrate that hypothermic hearts provide greater functional

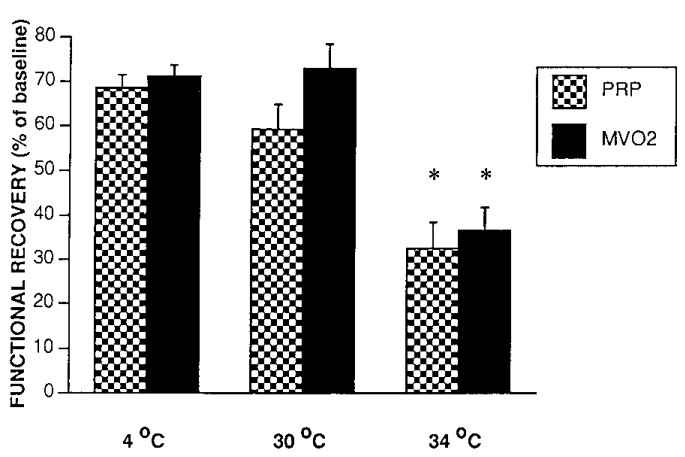

FIG. 2. Effect of hypothermia on functional recovery during reperfusion. The reperfused cardiac function parameters are plotted as a percentage of baseline $\left(37^{\circ} \mathrm{C}\right)$. The abbreviations used are: PRP, product of $\mathrm{HR}$ and $\mathrm{DP} ; \mathrm{MV}_{\mathrm{O}_{2}}$, myocardial oxygen consumption. ${ }^{*} P<0.05$ vs $4^{\circ} \mathrm{C}$. recovery than those observed in the $34^{\circ} \mathrm{C}$ hearts. There were no significant differences between hearts after 4 and $30^{\circ} \mathrm{C}$ ischemia. The hypothermic hearts were characterized by higher developed pressures, higher $\pm d P / d t_{\max }$ values, higher products of heart rate and DP, and higher myocardial oxygen consumption, indicating that heart function was improved in the hypothermic groups.

Ischemic contracture. As noted under Materials and Methods, a specific balloon volume was adjusted and maintained throughout the experiment, allowing comparisons of left ventricular pressure under constant end-diastolic volume. After injecting cardioplegic solution, the left ventricular pressure was always near 0 $\mathrm{mm} \mathrm{Hg}$. The beginning of ischemic contracture was defined by the initial rise in left ventricular pressure above $2 \mathrm{~mm} \mathrm{Hg}$. Ischemic contracture started in the $34^{\circ} \mathrm{C}$ control group after $64.9 \pm$ $4.8 \mathrm{~min}$ of ischemia but there was no contracture in the hypothermic groups. 


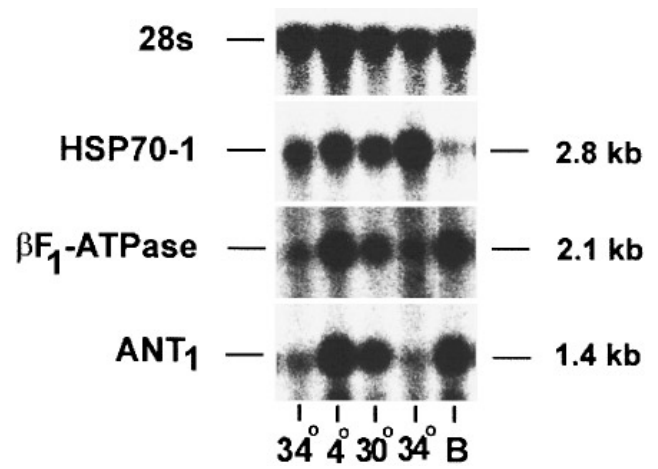

FIG. 3. A representative Northern blot. Each lane was loaded with $15 \mu \mathrm{g}$ total RNA from ventricular myocardium and probed specifically for $28 \mathrm{~s}, \beta \mathrm{F}_{1}$-ATPase, $\mathrm{ANT}_{1}$, and HSP70-1. Samples were taken from hearts at baseline control and after $2 \mathrm{~h}$ ischemia at 4,30 , or $34^{\circ} \mathrm{C}$ followed by 45 min reperfusion (see text). The abbreviations used are: $4^{\circ}$, $30^{\circ}$, and $34^{\circ}$, ischemic temperature at 4,30 , and $34^{\circ} \mathrm{C}$, respectively; $\mathrm{B}$, baseline.

\section{$A N T_{1}, \beta F_{1}$-ATPase, and HSP70-1 mRNAs}

Representative Northern blot analyses for mRNAs of $\mathrm{ANT}_{1}, \beta \mathrm{F}_{1}$-ATPase, and HSP70-1 are shown in Fig. 3. Compared to hearts perfused at baseline, both 4 and $30^{\circ} \mathrm{C}$ treatment resulted in no significant differences in mRNA levels. Steady-state mRNA levels for $\mathrm{ANT}_{1}$ $\beta \mathrm{F}_{1}$-ATPase and HSP70-1, normalized to $28 \mathrm{~s}$ ribosomal RNA intensity, are shown in Figs. 4 and 5 for tissue obtained during the protocol. On the other hand, postischemic steady-state levels of $\mathrm{ANT}_{1}$ and $\beta \mathrm{F}_{1}$-ATPase mRNA was

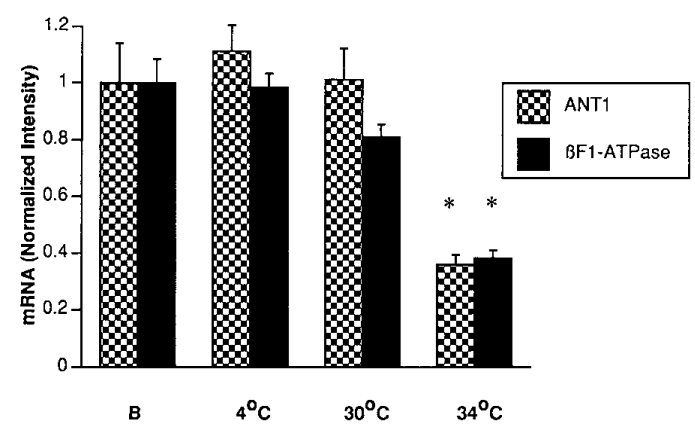

FIG. 4. Steady-state mRNA levels of $\mathrm{ANT}_{1}$ and $\beta \mathrm{F}_{1}$ ATPase. All transcript levels are relative to the $28 \mathrm{~s}$ band intensity and normalized to the $\mathrm{B}$ lane. Abbreviations are defined in the legend to Fig. 3 . ${ }^{*} P<0.05$ vs $\mathrm{B}$.

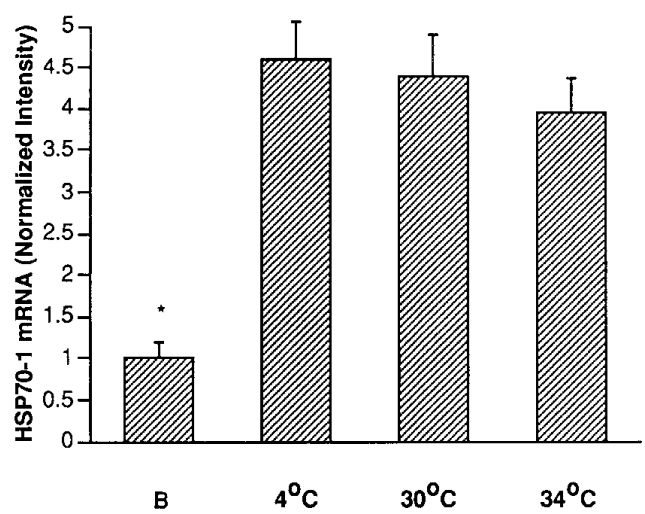

FIG. 5. Steady-state mRNA levels of HSP70-1. All mRNA levels are relative to the $28 \mathrm{~s}$ band intensity and normalized to the $\mathrm{B}$ lane. Abbreviations are defined in the legend to Fig. 3. ${ }^{*} P<0.05$ vs $34^{\circ} \mathrm{C}$.

markedly diminished in $34^{\circ} \mathrm{C}$ hearts (Figs. 3 and 4). The HSP70-1 mRNA level was fourfold higher in $34^{\circ} \mathrm{C}$ ischemic hearts than baseline condition and there were no noticeable differences from that in 4 and $30^{\circ} \mathrm{C}$ ischemia (Fig. 5).

\section{DISCUSSION}

Previous work using the current model demonstrated that preservation of postischemic function was closely related to ATP levels during reperfusion $(25,27,28)$. These levels cannot be considered indices of mitochondrial function or damage, as they are dependent on the balance between energy production and utilization during ischemia, as well as the status of the purine salvage pathways (30). Reductions in ATP utilization caused by temperatures below the threshold preserve ATP stores during ischemia and prevent nucleotide loss through purine degradation pathways (27). Preservation of ATP or rapid restoration during reperfusion ensures continuation of processes, which are ATP dependent. These processes clearly include those utilizing ATPases for energy conversion, such as the myosin-actin interaction.

However, the role of maintained ATP stores in preservation of pathways necessary for the cardiomyocyte to initiate repair after ischemia has not been fully established. These pathways might include those responsible for mitochon- 
drial repair as mitochondrial dysfunction and damage occur during hypoxia/ischemia and reoxygenation or reperfusion (30). This dysfunction has been linked to reductions in activities of both the adenine nucleotide translocator and the mitochondrial ATPase $(8,14)$. The adenine nucleotide translocator and the $\beta \mathrm{F} 1$ ATPase together account for greater than $30 \%$ of mitochondrial protein (12). Logically, one might assume that restoration of normal mitochondrial function following ischemic injury would require resynthesis and/or reconfiguration of these major mitochondrial membrane proteins $(1,4,10,11,23,32,37)$. As expression of the adenine nucleotide translocator protein in particular closely coordinates with steady-state mRNA levels for the corresponding gene (31), one would expect that preserved gene expression would be necessary for eventual protein resynthesis. Maintenance of ATP levels have been closely linked to preservation of these mRNA levels, which are considered indices of signaling for mitochondrial biogenesis (28). Similarly, the current studies demonstrate preservation of steady-state mRNA levels after ischemia at the critical temperature or below, where we have previously demonstrated reductions in ATP depletion (27).

Increased expression of cytosolic heat shock proteins such as HSP70-1 has been related to preserved myocardial function after reperfusion $(5,18,22,24)$. The mechanisms responsible for this relationship are not fully elucidated. However, cytosolic stress proteins do interact with mitochondrial protein precursors in the cytoplasm $(16,34)$, prevent their aggregation, and promote their import across the mitochondrial membrane. Stress agents such as heat shock or hypothermia applied prior to ischemia enhance HSP-70 expression in isolated hearts or cells after ischemia $(5,13,20,22,29)$. Application of these stress agents yields a substantial elevation in steady-state HSP70-1 mRNA during reperfusion in isolated rabbit hearts (28). Previously, a near 12-fold increase in these steady-state levels occurred after hypothermic adaptation and subsequent ischemia (28). In comparison, the current protocol produced a modest 4 -fold increase in HSP70-1 mRNA after reperfusion. This elevation occurred at all levels of ischemic temperature studied during these experiments. This may be considered a response to ischemia, but it does not appear to be ischemic temperature dependent and does not relate to the level of postischemic myocardial function or ATP preservation.

In summary, these data show that maintenance of postischemic steady-state mRNA levels for $\mathrm{ANT}_{1}$ and the $\beta \mathrm{F}_{1}$-ATPase occurs at or below the previously defined critical temperature $\left(30^{\circ} \mathrm{C}\right)$ for superior postischemic ATP and cardiac function preservation. Preservation of these mRNA levels implies, though does not prove, that the corresponding protein levels will be amplified. However, these data provide the basis of a novel hypothesis, whereby hypothermia promotes myocardial protection through maintenance of transcriptional signaling pathways.

\section{ACKNOWLEDGMENTS}

This study was supported in part by a grant from NIH (HL47805). We thank Dr. Shi-Han Chen, Dr. Yue Yao, and Dr. W. G. Guntheroth, Department of Pediatrics, and Dr. Linghen Li, Department of Molecular Biotechnology, for advice and counsel.

\section{REFERENCES}

1. Bailey, J. R., and Driedzic, W. R. Decreased total ventricular and mitochondrial protein synthesis during extended anoxia in turtle heart. Am. J. Physiol. 265, R1660-R1667 (1996).

2. Behrendt, D. M., and Jochim, K. E. Effect of temperature of cardioplegic solution. J. Thorac. Cardiovasc. Surg. 76, 353-357 (1978).

3. Corno, A. F., Bethencourt, D. B., Laks, H., Haas, G. S., Bhuta, S., Davtyan, H. G., Flynn, W. M., Drinkwater, D. C., Laidig, C., and Chang, P. Myocardial protection in the neonatal heart, a comparison of topical hypothermia and crystalloid and blood cardioplegic solutions. J. Thorac. Cardiovasc. Surg. 93, 163-171 (1987).

4. Garboczi, D. N., Fox, A. H., Gerring, S. L., and Pedersen, P. L. $\beta$ Subunit of rat liver mitochondrial ATP synthase: cDNA cloning, amino acid sequence, expression in Escherichia coli, and structural relationship to adenylate kinase. Biochemistry 27, 553-560 (1988).

5. Heads, R. J., Latchman, D. S., and Yellon, D. M. Differential stress protein mRNA expression during 
early ischaemic preconditioning in the rabbit heart and its relationship to adenosine receptor function. $J$. Mol. Cell. Cardiol. 27, 2133-2148 (1995).

6. Hearse, D. J., Stewart, D. A., and Braimbridge, M. V. The additive protective effects of hypothermia and chemical cardioplegia during ischemic cardiac arrest in the rat. J. Thorac. Cardiovasc. Surg. 79, 39-43 (1980).

7. Hendry, P. J., Masters, R. G., and Haspect, A. Is there a place for cold crystalloid cardioplegia in the 1990s? Ann. Thorac. Surg. 58, 1690-1694 (1994).

8. Henke, W., and Jung, K. Ischemia decreases the content of the adenine nucleotide translocator in mitochondria of rat kidney. Biochim. Biophys. Acta 1056, 71-75 (1991).

9. Illes, R. W., Wright, J. K., Inners-McBride, K., Yang, C-J., and Tristank, A. Ischemic preconditioning improves preservation with crystalloid cardioplegia. Ann. Thorac. Surg. 58, 1481-1485 (1994).

10. Izquierdo, J. M., and Cuezva, J. M. Evidence of posttranscriptional regulation in mammalian mitochondrial biogenesis. Biochem. Biophys. Res. Commun. 196, 55-60 (1993).

11. Izquierdo, J. M., Ricart, J., Ostronoff, L. K., Egea, G., and Cuezva, J. M. Changing patterns of transcriptional and post-transcriptional control of $\beta \mathrm{F}_{1}$ ATPase gene expression during mitochondrial biogenesis in liver. J. Biol. Chem. 263, 7767-7775 (1995).

12. Klingenberg, M. Dialectics in carrier research: The ADP/ATP carrier and the uncoupling protein. J. Bioenerg. Biomemb. 25, 447-457 (1993).

13. Knowlton, A. A., Eberli, F. R., Brecher, P., Romo, G. M., Owen, A., and Apstein, C. S. A single myocardial stretch or decreased systolic fiber shortening stimulates the expression of heat shock protein 70 in the isolated, erythrocyte perfused rabbit heart. J. Clin. Invest. 88, 2018-2025 (1991).

14. Kobara, M., Tatsumi, T., Matoba, S., Yamahara, Y., Nakagawa, C., Ohta, B., Matsumoto, T., Inoue, D., Asayama, J., and Nakagawa, M. Effect of ischemic preconditioning on mitochondrial oxidative phosphorylation and high energy phosphates in rat hearts. J. Mol. Cell. Cardiol. 28, 417-428 (1996).

15. Kohno, H., Toshima, Y., Nakamura, Y., Masuda, M., Morita, S., Asout, T., Shiki, K., Tanaka, J., and Tokunaga, K. Beneficial effects of hypothermic reperfusion on metabolic and functional recovery after cold storage of the rat heart. J. Heart Transplant. 6, 49-53 (1987).

16. Komiya, T., and Mihara, K. Protein import into mammalian mitochondria. Characterization of the intermediates along the import pathway of the precursor into the matrix. J. Biol. Chem. 271, 22105-22110 (1996).

17. Konishi, T., Nomoto, M., Shimizu, K., Abe, T., Itoh, H., Friedrich, H., Gunther, E., and Higashi, K. Dom- inant role of the second heat shock element in expression of the HSP70-1 gene in rat liver after whole body hyperthermia. J. Biochem. 118, 1021-1029 (1995).

18. Kumar, K., Wu, X., Evans, A. T., and Marcoux, F. The effect of hypothermia on induction of heat shock protein (HSP)-72 in ischemic brain. Metab. Brain Dis. 10, 283-291 (1995).

19. Ledingham, S. J. M., Braimbridge, M. V., Hearse, D. J. The St. Thomas' Hospital cardioplegic solution: A comparison of the efficacy of two formulations. J. Thorac. Cardiovasc. Surg. 9, 240-246 (1987).

20. Liu, A. Y., Bian, H., Huang, L. E., and Lee, Y. K. Transient cold shock induces the heat shock response upon recovery at $37^{\circ} \mathrm{C}$ in human cells. J. Biol. Chem. 269, 14768-14775 (1994).

21. Matz, J. M., Blake, M. J., Tatelman, H. M., Lavoi, K. P., Holbrook, N. J., and Dakota, G. F. Characterization and regulation of cold-induced heat shock protein expression in mouse brown adipose tissue. Am. J. Physiol. 269, R38-R47 (1995).

22. McCully, J. D., Myrmel, T., Lotz, M. M., Krukenkamp, I. B., and Levitsky, S. The rapid expression of myocardial HSP 70 mRNA and the heat shock $70 \mathrm{kDa}$ protein can be achieved after only a brief period of retrograde hyperthermic perfusion. J. Mol. Cell. Cardiol. 27, 873-882 (1995).

23. Neckelmann, N., Li, K., Wade, R. P., Shuster, R., and Wallace, D. C. cDNA sequence of a human skeletal muscle ADP/ATP translocator: Lack of a leader peptide, divergence from a fibroblast translocator c DNA, and coevolution with mitochondrial DNA genes. Proc. Natl. Acad. Sci. USA 84, 7580-7584 (1987).

24. Myrmel, T., McCully, J. D., Malikin, L., Krukenkamp, I. B., and Levitsky, S. Heat-shock protein 70 mRNA is induced by anaerobic metabolism in rat hearts. Circulation 90(5 Pt 2), II299-305 (1994).

25. Ning, X-H., Childs, K. F., and Bolling, S. F. Glucose level and myocardial recovery after warm arrest. Ann. Thorac. Surg. 62, 1825-1829 (1996).

26. Ning, X-H., Ding, X., Chills, K. F., Bolling, S. F., and Gallagher, K. P. Flavone improves functional recovery after ischemia in isolated reperfused rabbit hearts. J. Thorac. Cardiovasc. Surg. 105, 541-549 (1993).

27. Ning, X-H., Xu, C. S., Song, Y. C., Childs, K. F., Xiao, Y., Bolling, S. F., Lupinetti, F. M., and Portman, M. A. Temperature threshold and modulation of energy metabolism in the cardioplegic arrested rabbit heart. Cryobiology 36, 2-11 (1998).

28. Ning, X-H., Xu, C. S., Song, Y. C., Xiao, Y., Hu, Y. J., Lupinetti, F. M., and Portman, M. A. Hypothermia preserves function and signaling for mitochondrial biogenesis during subsequent ischemia in isolated rabbit heart. Am. J. Physiol. 274, H786-H793 (1998).

29. Plumier, J. C., Robertson, H. A., and Curri, R. W. Differential accumulation of mRNA for immediate early 
genes and heat shock genes in heart after ischaemic injury. J. Mol. Cell. Cardiol. 28, 1251-1260 (1996).

30. Portman, M. A., Standaert, T. A., and Ning, X-H. Relation of myocardial oxygen consumption and function to high energy phosphate utilization during graded hypoxia and reoxygenation in sheep in vivo. J. Clin. Invest. 95, 2134-2142 (1995).

31. Portman, M. A., Xiao, Y., Song, Y., and Ning, X-H. Expression of the adenine nucleotide translocator parallels maturation of respiratory control in heart in vivo. Am. J. Physiol. 273, H1977-H1983 (1997).

32. Rouslin, W. Mitochondrial complexes I, II, III, IV, and $\mathrm{V}$ in myocardial ischemia and autolysis. Am. J. Physiol. 244, H743-H748 (1983).

33. Schatz, G., and Dobberstein, B. Common principles of protein translocation across membranes. Science 271, 1519-1526 (1996).

34. Shragge, B. W., Digerness, S. B., and Blackstone, E. H. Complete recovery of the heart following exposure to profound hypothermia. J. Thorac. Cardiovasc. Surg. 81, 455-458 (1981).
35. Stepien, G., Torroni, A., Chung, A. B., Hodge, J. A., and Wallace, D. C. Differential expression of adenine nucleotide translocator isoforms in mammalian tissues and during muscle cell differentiation. J. Biol. Chem. 267, 14592-14597 (1992).

36. Tyers, G. F. O., Williams, E. H., Hughes, H. C., and Todd, G. J. Effect of perfusate temperature on myocardial protection from ischemia. J. Thorac. Cardiovasc. Surg. 73, 766-771 (1977).

37. Williams, R. S., Garcia-Moll, M., Salmons, S., and Harlan, W. Adaptation of skeletal muscle to increased contractile activity. J. Biol. Chem. 262, 2764-2767 (1987).

38. Wittnich, C., Vincenti, W., and Salerno, T. A. Comparison of mild and deep hypothermia: Do they provide similar protection in all neonatal hearts? Can. J. Surg. 34, 317-320 (1991).

39. Xu, C. S., Song, Y., Xiao, Y., Childs, K. F., Bolling, S. F., Portman, M. A., and Ning, X-H. The critical temperature point to resist ischemia in rabbit hearts. FASEB J. 10(3), A36 (1996). 